\title{
Archaeology and Biogeography of the Western Pond Turtle (Actinemys marmorata) in the Puget Sound Region
}

\author{
Jacob L. Fisher ${ }^{1^{*}}$ \\ ${ }^{1}$ Department of Anthropology, California State University, Sacramento, CA \\ *jlfisher@csus.edu
}

\begin{abstract}
The modern distribution of the western pond turtle (Actinemys marmorata) is discontinuous, with a historic but extirpated population in the Puget Sound region that was isolated from populations south along the Columbia River. To better understand this distribution, a review of the archaeological literature for the Puget Sound region was conducted to determine the prehistoric biogeography of the species in the Puget Sound area. Western pond turtles are nearly absent from the regional archaeological record, represented at best by four tentative specimens. This may be explained by extremely low population levels throughout the Holocene at the northernmost extent of its range.
\end{abstract}

Received January 11, 2018

OPEN ӘACCESS

Accepted May 8, 2018

DOI 10.14237/ebl.9.2.2018.1228

Keywords Zooarchaeology; Actinemys marmorata; Conservation biology; Biogeography; Washington State

Copyright (C) 2018 by the author(s) licensee Society of Ethnobiology. This is an open-access article distributed under the terms of the Creative Commons Attribution-NonCommercial 4.0 International Public License (https://creativecommons.org/licenses/by-nc/4.0), which permits non-commercial use, distribution, and reproduction in any medium, provided the original author and source are credited.

\section{Introduction}

The western pond turtle, Actinemys marmorata (formerly Clemmys marmorata; Crother et al. 2003; Feldman and Parham 2002), is the only freshwater turtle native to western Washington. With an estimated population of 250-350 individuals in Washington, it is currently listed by the state as an endangered species (Hays et al. 1999); limited genetic variation in modern populations combined with anthropogenic impacts seriously threatens the survival of this species (Gray 1995; Spinks and Shaffer 2005).

Conservation efforts would benefit from a more thorough understanding of the historic dynamics of the species, especially at the northernmost extent of its range where $A$. marmorata is more likely to have been impacted by long-term climatic changes that may affect reproductive rates, duration of hibernation, and availability of food resources. The archaeofaunal record may be used to establish the prehistoric biogeography of the species by providing critical temporal and geographic data in the absence of adequate paleontological datasets. Considering the role turtles and their relatives play in many foraging societies as a subsistence resource and often in ceremonial realms, it is expected that their remains should be recovered from archaeological deposits. If the species was a preferred resource, as suggested by the archaeological record of other regions, the abundance of local populations should be reflected by their abundance in the archaeological record. To this end, the archaeological and ethnographic literature for the region was reviewed to better understand the biogeography of the species, supplemented by a review of faunal materials recovered from the Duwamish No. 1 site (45KI23) in Seattle.

\section{Historic Distribution}

A. marmorata is a highly aquatic species, living in freshwater (and tolerant of brackish water) streams, ponds, lakes, and wetlands (Figure 1). Historically, the species had a continuous range from the Columbia River south to Baja California, with isolated populations in the Great Basin (Mojave, Truckee, Carson, and Humboldt rivers) and the Puget Sound (Bury et al. 2008; Figure 2). In the Pacific Northwest, individuals have been observed at elevations ranging from $0-300 \mathrm{~m}$ and remain active in water temperatures between $1-2^{\circ} \mathrm{C}$ and $38^{\circ} \mathrm{C}$. The species must have colonized the Puget Sound after the deglaciation of the region at the end of the Pleistocene (Hays et al. 1999; Spinks and Shaffer 2005). This allopatric population may have formed when a pyroclastic event from Mount Rainer created a 


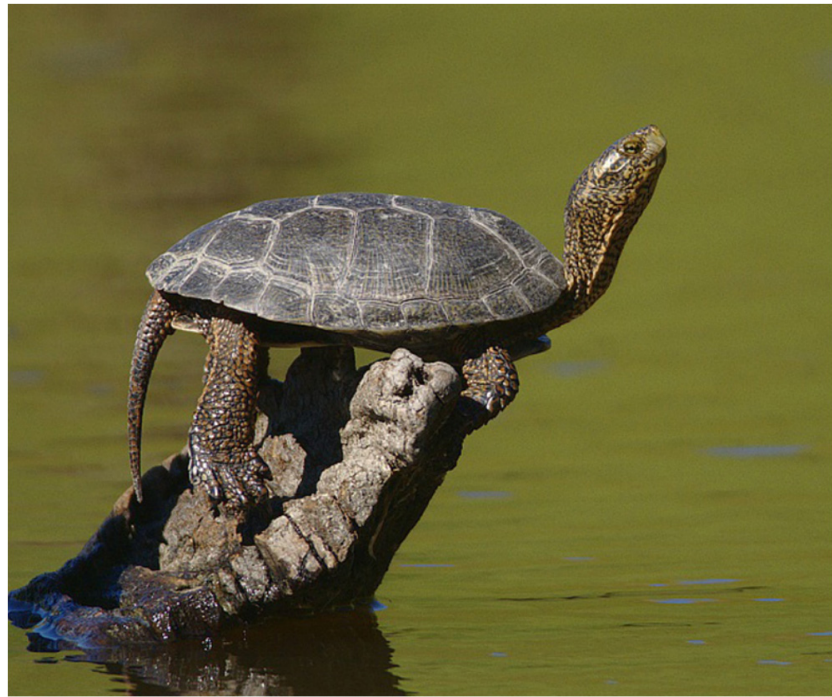

Figure 1 Western pond turtle from California. By Yathin S. Krishnappa CC BY-SA 3.0, https:// commons. wikimedia.org/w/index. php?curid=21284381.

barrier from Columbia River populations about 4,700 BP (Hays et al. 1999:3). The earliest scientific specimens of western pond turtle, obtained in 1841, originate from the Puget Sound region (Baird and Girard 1852:177).

There is low genetic variability in the northern populations of $A$. marmorata, supporting evidence of a recent Holocene expansion of their range (Gray 1995; Janzen et al. 1997; Spinks and Shaffer 2005). Moreover, Spinks and Shaffer (2005) note that the Puget Sound population does not conform to the general pattern of north-south genetic divergence, and it appears that this population is less closely related to the Columbia River populations than it is to populations further south. The Oregon, Washington, and Mojave River populations display a high degree of genetic similarity that reflects a lack of dispersal and gene flow and may be a consequence of habitat fragmentation (Gray 1995; Lovich and Meyer 2002; Spinks and Shaffer 2005). Throughout this range, pond turtle populations continue to dwindle due to a variety of factors, including habitat fragmentation, competition with non-native species, and possibly a lack of genetic variability.

By the 1980s, Puget Sound populations were nearly extirpated with only isolated individuals observed in the 1990s. Hays and colleagues (1999:ix) state that commercial exploitation of pond turtles for consumption in the late 1800 s likely reduced the
Puget Sound population to unsustainable levels by the 1930s, but they provide only a personal communication as support. They note that Cooper observed that turtles were "common in freshwater ponds and rivers west of the Cascades" in the 19th century (Cooper 1859), and that their historic abundance was later questioned by Storer (1937) based on his observations several decades later. Hays et al. (1999) offer three reasons for the scarcity observed by Storer in the 1930s: (1) elusiveness due to the wary nature of the species, (2) low population numbers at the northernmost limit of its range, or (3) historic reductions that occurred prior to collecting activities in the 1930s (Hays et al. 1999:16). Hays and colleagues implicitly favor the lattermost explanation.

The possibility that western pond turtle populations were always low may be investigated using the archaeological record. There has been great success in the use of archaeofaunal data to establish the prehistoric biogeography of a variety of species (e.g., Dombrosky et al. 2016; Fisher 2012). Turtles are commonly exploited as a subsistence resource by small-scale foragers, and their abundance and distribution in the archaeological record should be a reflection of the prehistoric population dynamics in response to environmental change at northern latitudes. If $A$. marmorata historic populations were large enough to be commercially exploited, as alleged by Hays and colleagues (1999), they are expected to occur in archaeological deposits at relatively high rates throughout the late Holocene. On the other hand, if populations were always low, archaeofaunal specimens should be rare.

\section{Archaeological Expectations}

Despite their relatively small package size, turtles arguably are attractive as a prey species due to the ease of capture and the low processing costs. In the southern range of $A$. marmorata, Native Californians harvested turtles using underwater traps and nets specifically made for this purpose or captured them by hand by diving (e.g., Latta 1999). A. marmorata may also be collected on land during the winter and summer months when they leave the water to hibernate or aestivate, and females (and their eggs) could have been gathered when encountered during nesting season. Females nest in relatively predictable locations, favoring areas with sparse and low vegetation, hard and dry soil, and above the floodplain (Holland 1994). Additionally, there may be some degree of nest site philopatry, with females returning 


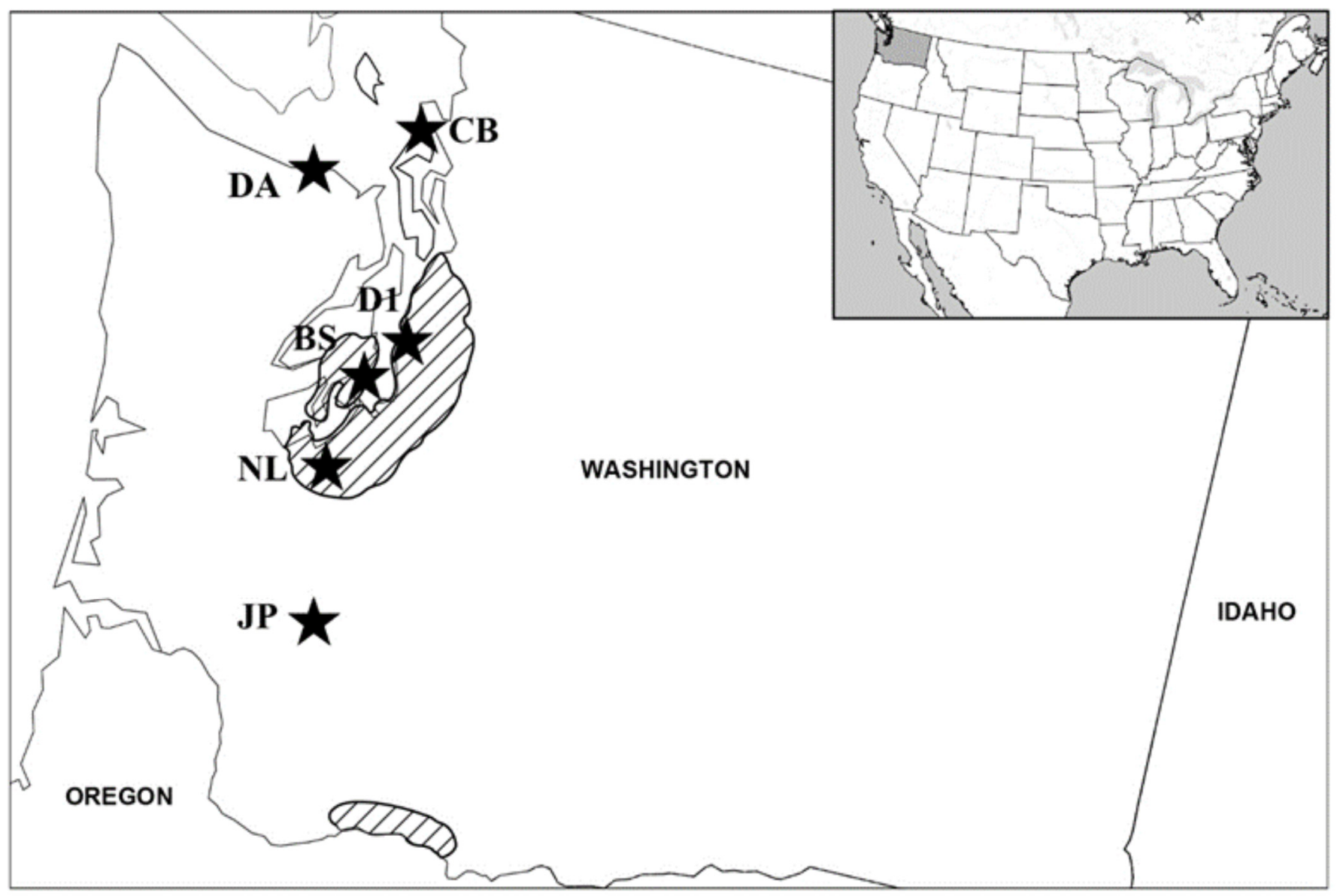

Figure 2 Approximate historic range (circa 1850) of Actinemys marmorata in Washington (adapted from Hays et al. [1999: Figure 1]) and select locations mentioned in text. $C B=C o r n e t$ Bay, $D A=$ Daishowa America Site, BS=Bay Street Midden, JP=Judd Peak Rockshelter, D1=Duwamish No. 1 Site, NL=Nisqually Lake.

to their birthplace to nest, and as a result, modern populations tend to be male-biased due to predation on nesting females (Holland 1994). This predictable behavior would allow easy gathering by people who knew that this resource would be available around the month of June. It is also likely that turtles were fortuitously acquired during other subsistence activities such as fishing. Once obtained, it is unlikely that people would have disposed of them unless there were significant processing costs. Judging from ethnographic data from California, where turtles were often simply placed over hot coals and consumed without any further preparation (e.g., Loeb 1926), the post-encounter processing costs are likely to be very low.

The potentially low costs of acquiring and processing turtles would explain why turtles are frequently found throughout prehistory, including in some of the earliest archaeological assemblages. The European pond turtle (Emys orbicularis) appears early in the Italian Middle Paleolithic, circa 55,000 years ago (Stiner et al. 2000); this species is genetically and behaviorally similar to $A$. marmorata (Spinks and Shaffer 2005). Likewise, there is a high frequency of turtle and tortoise specimens in North American Clovis period sites dating to ca. 11,050 to 10,800 radiocarbon years ago (Waguespack and Surovell 2003). In eastern Washington, the painted turtle (Chrysemys picta) comprises over half of the reptile and amphibian remains (total NISP $=2,746$ ) in northern Columbia Plateau assemblages dating to 7000-150 BP (Butler and Campbell 2004). The species of interest here, A. marmorata, appears in early Holocene sites along the Santa Barbara coast (Erlandson 1994), and its use by Native Californians and Oregonians is well 
established ethnographically (e.g., Latta 1999; Loeb 1926).

In addition to serving as a subsistence item, turtles may also enter the archaeological record as artifacts used for ritual and utilitarian purposes, such as turtle-shell rattles or bowls (e.g., Gillreath-Brown and Peres 2017). Such artifacts may be curated for long periods of time and transported great distances, complicating the general assumption that archaeofaunal remains represent local turtle populations. For example, specimens of $A$. marmorata that exhibit polishing and drilling indicative of nonfood use have been found in western Nevada, making it difficult to determine whether they represent local populations or were transported as artifacts over the Sierra Nevada crest from California (Hattori 1982). Isolated specimens found well beyond the historic range of a taxon likely represent curated artifacts.

\section{Prehistoric Record of Actinemys marmorata in Puget Sound}

Considering the antiquity of turtle use, the potential importance of turtles as a dietary resource, and the reported commercial harvesting in the historic period, one would expect $A$. marmorata to be relatively conspicuous in the Puget Sound archaeological record. Published reports and gray literature (i.e., cultural resource management reports) on excavations throughout western Washington were reviewed to identify archaeological occurrences of $A$. marmorata in an effort to establish the prehistoric distribution of the species.

Only four sites have possible turtle remains, two of which are identified specifically to $A$. marmorata (Figure 2). One specimen is a single plastron fragment found at Cornet Bay (45IS31b) on the north end of Whidbey Island in deposits dating from circa $2500 \mathrm{BP}$ to historic contact (Weasma 1991). Cornet Bay is approximately $80 \mathrm{~km}$ north of the northernmost historical occurrence of $A$. marmorata. Hays and colleagues (1999) suggest that the individual could have been transported for food. However, the identification of the specimen as A. marmorata is questionable, as the original report states: "The plastral fragment in the [Cornet Bay] fauna does not conform exactly to the few specimens of $[A$. marmorata] at hand" (Weasma 1991:10). It is possible that this specimen is instead C. picta obtained as an artifact from eastern Washington. Considering that both species are of the same family (Emydidae), the lack of conformity with $A$. marmorata may be due to misidentification. Unfortunately, the Cornet Bay specimen could not be located for evaluation in the site collection housed at the Burke Museum, University of Washington. The second specimen identified as $A$. marmorata is from the Bay Street Shell Midden (45KP115), a site on the Kitsap Peninsula that dates between AD 1150 and 1750 (Lewarch et al. 2002). Although it is listed as A. marmorata, it is unknown how this assessment was made. Notably, both sites contain relatively late deposits.

There are two additional occurrences that were not specifically identified as $A$. marmorata. At the Daishowa America site (45CA415), one fragment of turtle carapace was found in a stratum dating to $880 \pm$ 60 to $590 \pm 80 \mathrm{BP}$, but it is only listed as Testudinidae (Lewarch et al. 1992). This site is located near Port Angeles on the north shore of the Olympic Peninsula, far outside of the historic range of $A$. marmorata. The Testudinidae family consists of tortoises, none of which occur in Washington State. The order Testudines includes all turtles, tortoises, and terrapins; considering that sea turtles have been observed in the region historically, this specimen may instead be from the family Cheloniidae. The fourth possible archaeological occurrence of turtle in western Washington is from Judd Peak Rockshelter South (45LE222), where it is recorded that specimens from "a large frog or toad and possibly turtle" were present in contexts dating between $5970 \pm 100$ to $310 \pm 50$ BP (Daugherty et al. 1987). No further information is available on this material.

In each of the four cases, there is a significant degree of uncertainty in the identification that may be addressed using skeletal morphology, genetics, or ZooMS. It may also be significant that the two cases that explicitly note the skeletal part involve carapace or plastron fragments, the portion that is often transformed into cultural artifacts that may have traveled great distances through exchange networks from eastern Washington or the Columbia River.

The near absence of prehistoric $A$. marmorata specimens in the Puget Sound region may reflect some challenges when using the archaeological record to reconstruct prehistoric biogeography: turtle remains may not be present due to taphonomic processes, or remains that are recovered were not correctly identified as turtle due to research biases. The acidic soils of the Northwest Coast are not favorable for bone preservation, and most vertebrate faunal remains come from shell middens. Yet, a 
significant number of such sites have been excavated in the region and these are frequently located near habitats of $A$. marmorata. It thus seems unlikely that the near absence of turtles in the archaeological record is due to taphonomy.

Alternatively, turtle specimens may be recovered but not be correctly identified in the region due to research biases. Herptofaunal remains are often deemphasized in zooarchaeological training and analysis. For example, Olson states in a zooarchaeology methodology section of one report: "The final category is undetermined/other. This includes all those faunal items that could not be distinguished into the above broad size categories plus reptile remains" (Olson, in Schalk 1980:263, emphasis added). When specimens are identified as being turtle, they are often only identified to a nonspecific level, such as "turtle" or "Testudinidae" (see Schneider and Everson 1989 for similar critique). Even when specimens are identified to the species level, it is often done on the basis of modern distributions and not diagnostic skeletal morphology. This is problematic for a variety of reasons (Driver 2011), and the practice is counterproductive for biogeography studies due to the inherent circularity.

To evaluate the potential influence of methodological research biases, the unidentified vertebrate and invertebrate faunal assemblage from the Duwamish No. 1 site (45KI23) were searched for A. marmorata specimens. This site was selected due to its location and the presence of abundant faunal remains. This large shell midden is located on a lowlying terrace on the west bank of the Duwamish River in Seattle, Washington, close to the historic mouth of the river (Blukis Onat 1987). The location and presence of wetland species in the assemblage suggests that ideal habitats for the western pond turtle would have been present. Four occupations spanning at least 1000 years (AD 670-1700) are represented, providing a significant time span for understanding potential changes in western pond turtle abundances through time, if present. No turtle specimens were discovered among the unidentified remains $(\mathrm{n} \geq$ 10,000 specimens).

\section{Ethnographic Record of Actinemys marmorata in Puget Sound}

A literature review of the ethnography for the Puget Sound region resulted in a single mention of turtles (Drucker 1955, 1965; Haeberlin and Gunther 1930; Smith 1940, 1941). The single exception to the absence in ethnographic texts is found with the Nisqually. Hays and colleagues (1999:16-17) note that there are native accounts of gathering turtle eggs at Nisqually Lake, and that the Nisqually name for the lake translates to "place where the turtles come from"; Hays et al. (1999) provide no source for this information. Smith (1941:207) states that the name of Nisqually Lake is "yicáxtcabc," but provides no translation. Reporting on the survey of the Northern Pacific Railroad route in 1853 to 1855, Cooper (1859) noted that $A$. marmorata was found in the vicinity of Fort Steilacoom, approximately $15 \mathrm{~km}$ from Nisqually. Further, Cooper (1859:292) notes that turtles are called "El-la-chick" by the Nisqually, and turtles are transcribed to "?álašak" in a Lushootseed dictionary (Bates et al. 1994:368). This appears to be a cognate of $\sim$ alashik, the term for turtle in the Sahaptin language spoken on the lower mid-Columbia River above The Dalles (E. Hunn, pers. comm.).

Certainly, the absence of turtles in ethnographic literature does not necessitate a real absence in the environment. For example, Bettelheim (2005:27) notes that western pond turtles do not appear in Thomas Jefferson Mayfield's account of the Yokuts in San Joaquin Valley of California and only cursory mention of the species is made in Frank Latta's accounts of the Yokuts. This is in spite of large turtle populations in the region and their common occurrence in archaeofaunal assemblages of the region. However, considering that turtles are a common element of oral tradition and stories elsewhere on the Pacific coast and interior Northwest (e.g., Beavert 1974), it is likely meaningful that turtles are conspicuously absent from oral tradition and imagery in the Puget Sound region.

\section{Understanding the Contradiction}

If the observed rarity of $A$. marmorata is reflective of the actual population densities of this species in the region, the discrepancy between the prehistoric and historic records of abundance must be addressed. Four possible explanations are offered: (a) predation pressures maintained low population densities; (b) there was a late onset of environmental conditions favorable to $A$. marmorata reproduction; (c) there was a historic introduction into the region; and (d) the unverified report of commercial exploitation is incorrect and historic populations were in fact low.

Prehistoric predation pressures could have maintained low turtle population densities, with a historic rebound occurring due to environmental 
changes brought forth by catastrophic human population declines. Resource depression of taxa with low recruitment rates frequently occurs as a result of increases in human population densities, sedentism, and territoriality. When human populations radically decline, the reduction in hunting pressures allows previously depressed resources to rebound. In western North America, protohistoric rebound has been identified in artiodactyl, fish, and shellfish populations in California and Lower Columbia Valley of Oregon (e.g., Butler 2000; Fisher 2018). An argument that invokes climate-induced environmental change is similar to protohistoric rebound, and the two explanations are not exclusive of one another. Temperature has an effect on sex ratios in turtle populations due to temperature-dependent sex determination (Christie and Geist 2017; Geist et al. 2015), and western pond turtles on the central California coast appear to mature more rapidly than species in eastern North America (and presumably more northern latitudes) due to the warmer, Mediterranean climate (Germano and Rathbun 2008). Cooler conditions during the Little Ice Age (c. AD 1350-1850) were likely unfavorable to $A$. marmorata reproductive rates, and populations may have rebounded with climatic warming beginning in the mid-19th century.

There are several problems with these two scenarios. First, there is no evidence for resource depression outside of the Lower Columbia Valley despite high human population densities in the Pacific Northwest (Butler and Campbell 2004). Second, it is expected that turtle specimens would be consistently found, albeit rarely, in the archaeological record and mentioned in ethnographic literature if they were locally present. In regards to climate, remains should be recovered in earlier deposits when more favorable conditions were present, such as during the preceding Medieval Climatic Anomaly (c. AD 950-1300). Third, a population rebound would require reproductive rates that are unlikely to be met by this temperate species at its northernmost limit. Modern, post-Little Ice Age conditions are not necessarily favorable to the species considering that current conservation efforts are hampered by the cool summer temperatures that slow embryo development and decrease the likelihood that hatchlings will survive to adulthood (Hallock et al. 2016). Bearing this in mind, it is doubtful that rebound would occur rapidly enough to account for historically recorded abundances.
The discontinuous distribution of the species and rare observations in the archaeological and ethnographic record may be best explained by a historic introduction. Such introductions of western pond turtles have been suggested elsewhere based on genetic and historic data, including the populations in British Columbia and the Carson, Truckee, and Humboldt rivers of Nevada (Bury et al. 2008; Spinks and Shaffer 2005). The San Francisco turtle market obtained $A$. marmorata in the thousands from the Central Valley and North Coast ranges of California in the late 1800s, with the earliest documented commercial exploitation in 1863 (Bettelheim 2005). The introduction of $A$. marmorata to western Great Basin rivers undoubtedly occurred during the mid$19^{\text {th }}$ century, possibly by miners from the California goldfields (Hattori 1982). Certainly, a recent introduction would explain the lack of latitudinal genetic divergence. The Puget Sound population appears to be more closely related to northern California populations than the more geographically proximate Columbia River population (Spinks and Shaffer 2005:Table 2). Furthermore, the two archaeological specimens identified as $A$. marmorata both come from sites with relatively late prehistoric or early historic era deposits. Yet, western pond turtles were present in the Puget Sound region by 1841 when the species was first described; if an introduction occurred, it must have taken place prior to this date. Such a possibility was previously suggested by Storer, who notes: "As turtles are now quite likely to be transported from place to place by irresponsible persons the need for checking the situation in western Washington at an early date is evident" (1937:67). The Hudson Bay Company established Fort Nisqually in 1833 and was active in northern California about this time, and it is feasible that turtles were transported north and ultimately released into the wild. Notably, it may not be a coincidence that the single ethnographic mention of turtles comes from the Nisqually in the vicinity of the Hudson Bay Company post.

As with the first two scenarios, one problem with this explanation is that a presumably small introduced turtle population would have had to increase very rapidly to account for high historic abundances. This leads to the fourth explanation for the contradiction: the premise that populations were historically large enough to support commercial exploitation is incorrect. As previously noted, Hays and colleagues (1999) state that commercial exploitation was the primary cause for the initial demise of western 
Washington turtle populations, noting the lucrative market in 1890s San Francisco. However, no historic records are provided as support. To address this deficiency, an online search of newspaper archives from the Puget Sound region using key terms "turtle" and "terrapin" was conducted through Washington State Library (https://www.sos.wa.gov/library/ newspapers_wsl.aspx\#historic) and Newspapers.com. While turtle soup, turtle doves, and the expression "turning turtle" (a capsized vessel or turned automobile) were common hits, there was not a single reference to local exploitation of turtle populations. Considering this, we may "turn turtle" on the premise that Puget Sound populations were abundant in the $19^{\text {th }}$ century and conclude that the vague historic baseline of high population abundance is simply incorrect until evidence to the contrary is brought forth. Instead, the bulk of the evidence indicates that the abundance of western pond turtles in the Puget Sound region was always low, if not an early historic introduction.

\section{Conclusions}

The dietary use of chelonians is so well established in other regions, even in some of the earliest human economies, that it is notable that $A$. marmorata is nearly absent in Puget Sound archaeological collections and the ethnographic literature. Four possible turtle specimens have been recorded in western Washington, two of which are identified as Actinemys marmorata. Significant problems are present with their identification, including the lack of attempts to identify chelonian specimens to the lowest taxonomic level possible and the use of historic distributions to make identifications. As others have noted (e.g., Driver 2011; Wolverton 2013), there must be methodological rigor in species identification and reporting. In particular, the use of historic distributions is a major hurdle in our ability to employ archaeofaunal assemblages for addressing prehistoric biogeography questions. Future work should reexamine the four tentative archaeological specimens to confirm the species identification combined with direct radiocarbon dating to determine whether western pond turtles were prehistorically present in western Washington. Even if the previously reported specimens are identified as western pond turtle that date well before the historic era, the extreme rarity of A. marmorata indicates that the population was never abundant in the Puget Sound region.

\section{Acknowledgements}

Burke Museum graciously provided access to the Cornet Bay and Duwamish No. 1 collections. Don Grayson provided early guidance on this research. Eugene Hunn provided assistance with translations. Matthew Bettelheim and Ben Fisher provided much appreciated insight on western pond turtle exploitation and natural history. Gissel Ruiz and Rachel Davies graciously reviewed earlier drafts of the manuscript. Lastly, I thank three anonymous reviewers for their insights.

\section{Declarations}

Permissions: Not applicable

Sources of Funding: Not applicable

Conflicts of Interest. None declared

\section{References Cited}

Baird, S.F. and C. Girard. 1852. Descriptions of New Species of Reptiles, Collected by the US Exploring Expedition under the Command of Capt. Charles Wilkes, U.S.N. Proceedings of the Academy of Natural Sciences of Philadelphia 6:174-177.

Barnett, H.G. 1939. Culture Element Distrbutions: IX Gulf of Georgia Salish. University of California Anthropological Records Volume 1. University of California Press, Berkeley, CA.

Bates, D., T. Hess, and V. Hilbert. 1994. Lushootseed Dictionary. University of Washington Press, Seattle, WA.

Beavert, V. 1974. The Way it Was, Anaku Iwacha: Yakima Legends. Franklin Press, Toppenish, WA.

Bettelheim, M. 2005. Marmorata: The Famed Mud Turtle of the San Francisco Market. California History 82:26-47. DOI:10.2307/25161765.

Blukis Onat, A.R., ed. 1987. Duwamish No. 1 Site: 1986 Data Recovery. Report Submitted to the Department of Archaeology and Historic Preservation, Olympia, WA.

Bury, R.B., D.J. Germano, A. Rhodin, P. Pritchard, and P. van Dijk. 2008. Actinemys marmorata (Baird and Girard 1852) - Western Pond Turtle, Pacific Pond Turtle. Conservation Biology of Freshwater Turtles and Tortoises: A Compilation Project of the IUCN/SSC Tortoise and Freshwater Turtle Specialist Group. Chelonian Research Monographs 5.

Butler, V.L. 2000. Resource Depression on the Northwest Coast of North America. Antiquity 74:649-661. DOI:10.1017/S0003598X00060014. 
Butler, V.L. and S.K. Campbell. 2004. Resource Intensification and Resource Depression in the Pacific Northwest of North America: A Zooarchaeological Review. Journal of World Prehistory 18:327-405. DOI:10.1007/s10963-004-5622-3.

Christie, N.E. and N.R. Geist. 2017. Temperature Effects on Development and Phenotype in a FreeLiving Population of Western Pond Turtles (Emys marmorata). Physiological and Biochemical Zoology 9:4753. DOI:10.1086/689409.

Cooper, J.G. 1859. Report upon the Reptiles Collected on the Survey. The Natural History of Washington Territory, with Much Relating to Minnesota, Nebraska, Kansas, Oregon, and California: Between the Thirty-Sixth and Forty-Ninth Parallels of Latitude, Being Those Parts of the Final Reports on the Survey of the Northern Pacific Railroad Route, Containing the Climate and Physical Geography, with Full Catalogues and Descriptions of the Plants and Animals Collected from 1853 to 1857. Baillière Brothers, New York, NY.

Crother, B.I., J. Boundy, J.A. Campbell, K. de Quieroz, D. Frost, D.M. Green, R. Highton, J.B. Iverson, R.W. McDiarmid, P.A. Meylan, T.W. Reeder, M.E. Seidel, J.W. Sites, S.G. Tilley, and D.B. Wake. 2003. Scientific and Standard English Names of Amphibians and Reptiles of North America North of Mexico: Update. Herpetological Review 34:198-203.

Daugherty, R.D., J.J. Flenniken, and J.M. Welch. Pacific Northwest. 1987. A Data Recovery Study of Judd Peak Rockshelters (45-LE-222) in Lewis County, Washington. Studies in Cultural Resource Management, No. 8. USDA-Forest Service, Pacific Northwest Region, Portland, OR.

Dombrosky, J., S. Wolverton, and L. Nagaoka. 2016. Archaeological Data Suggest Broader Early Historic Distribution for Blue Sucker (Cycleptus elongatus, Actinopterygii, Catostomidae) in New Mexico. Hydrobiologia 771:255-263. DOI:10.1007/s10750015-2639-9.

Driver, J.C. 2011. Identification, Classification, and Zooarchaeology. Ethnobiology Letters 2:19-39. DOI:10.14237/ebl.2.2011.32.

Drucker, P. 1955. Indians of the Northwest Coast. American Museum of Natural History, New York.

Drucker, P. 1965. Cultures of the North Pacific Coast. Chandler Pub. Co., San Francisco, CA.

Feldman, C.R., and J.F. Parham. 2002. Molecular Phylogenetics of Emydine Turtles: Taxonomic
Revision and the Evolution of Shell Kinesis. Molecular Phylogenetics and Evolution 22:388-398. DOI:10.1006/mpev.2001.1070.

Fisher, J.L. 2012. Shifting Prehistoric Abundances of Leporids at Five Finger Ridge, a Central Utah Archaeological Site. Western North American Naturalist 72:60-68. DOI:10.3398/064.072.0107.

Fisher, J.L. 2018. Protohistoric Artiodactyl Rebound and Resource Deinstensification in Northern California. Journal of Archaeological Science: Reports 19:420-429. DOI:10.1016/j.jasrep.2018.03.017.

Geist, N.R., Z. Dallara, and R. Gordon. 2015. The Role of Incubation Temperature and Clutch Effects in Development and Phenotype of Head-Started Western Pond Turtles (Emys marmorata). Herpetological Conservation and Biology 10:489-503.

Germano, D.J. and G.B. Rathbun. 2008. Growth, Population Structure, and Reproduction of Western Pond Turtles (Actinemys marmorata) on the Central Coast of California. Chelonian Conservation and Biology 7:188-194. DOI:10.2744/CCB-0705.1.

Gillreath-Brown, A. and T.M. Peres. 2017. Identifying Turtle Shell Rattles in the Archaeological Record of the Southeastern United States. Ethnobiology Letters 8:6. DOI:10.14237/ebl.8.1.2017.979.

Gray, E.M. 1995. DNA-Fingerprinting Reveals a Lack of Genetic-Variation in Northern Populations of the Western Pond Turtle (Clemmys marmorata). Conservation Biology 9:1244-1254. DOI:10.1046/ j.1523-1739.1995.9051234.x-i1.

Haeberlin, H.K. and E. Gunther. 1930. The Indians of Puget Sound. University of Washington Press, Seattle, WA.

Hattori, E.M. 1982. The Archaeology of Falcon Hill, Winnemucca Lake, Washoe County, Nevada. Nevada State Museum, Carson City, NV.

Hays, D.W., K.R. McAllister, S.A. Richardson, and D.W. Stinson. 1999. Washington State Recovery Plan for the Western Pond Turtle. Washington Department of Fish and Wildlife, Olympia, WA.

Holland, D. 1994. The Western Pond Turtle: Habitat and History. U.S. Department of Energy, Bonneville Power Administration, Portland, OR.

Hallock, L.A., A. McMillan, and G.J. Wiles. 2016 Periodic Status Review for the Western Pond Turtle in Washington (Draft). Washington Department of Fish and Wildlife, Olympia, WA. 
Janzen, F., S. Hoover, and H. Shaffer. 1997. Molecular Phylogeography of the Western Pond Turtle (Clemmys marmorata): Preliminary Results. Chelonian Conservation and Biology 2:623-626.

Latta, F.F. 1999. Handbook of Yokuts Indians, 2nd edition. Brewer's Historical Press, Exeter, CA.

Lewarch, D.E., L.A. Forsman, S.K. Kramer, L.R. Murphy, L.L. Larson, D.R. Iverson, and A.E. Dugas. 2002. Data Recovery Excavations at the Bay Street Shell Midden (45KP115), Kitsap County, Washington. Larson Anthropological/ Archaeological Services, Gig Harbor, WA.

Lewarch, D.E., L.L. Larson, L.S. Phillips, M. Daishowa, and S. Larson. 1992. Daishowa America Port Angeles Mill Shell Midden, 45CA415, Clallam County, Washington. LAAS Technical Report, No. 92-7. Larson Anthropological/Archaeological Services, Gig Harbor, WA.

Loeb, Edwin Meyer. 1926. Pomo Folkways. University of California Publications in American Archaeology and Ethnography 19:149-405.

Lovich, J. and K. Meyer. 2002. The Western Pond Turtle (Clemmys marmorata) in the Mojave River, California, USA: Highly Adapted Survivor or Tenuous Relict? Journal of Zoology 256:537-545. DOI:10.1017/s0952836902000584.

Schalk, R.F. 1980. Cultural Resource Investigations for the Second Powerhouse Project at McNary Dam, near Umatilla, Oregon. Laboratory of Archaeology and History, Washington State University, Pullman, WA.

Schneider, J.S., and G.D. Everson. 1989. Desert Tortoise (Xerobates agassizii) in the Prehistory of the Southwestern Great Basin and Adjacent Areas. Journal of California and Great Basin Anthropology 11:175-202.
Smith, M.W. 1940. The Puyallup-Nisqually. Columbia University Press, New York, NY.

Smith, M.W. 1941. The Coast Salish of Puget Sound. American Anthropologist 43:197. DOI:10.1525/ aa.1941.43.2.02a00050.

Spinks, P.Q. and H.B. Shaffer. 2005. Range-Wide Molecular Analysis of the Western Pond Turtle (Emys marmorata): Cryptic Variation, Isolation by Distance, and their Conservation Implications. Molecular Ecology 14:2047-2064. DOI:10.1111/ j.1365-294x.2005.02564.x.

Stiner, M.C., N.D. Munro, and T.A. Surovell. 2000. The Tortoise and the Hare: Small-Game Use, the Broad-Spectrum Revolution, and Paleolithic Demography. Current Anthropology 41:39-73. DOI:10.2307/3596428.

Storer, T.I. 1937. Further Notes on the Turtles of the North Pacific Coast of North America. Copeia 1937:66-67. DOI:10.2307/1437380.

Waguespack, N.M. and T.A. Surovell. 2003. Clovis Hunting Strategies or How to Make Out on Plentiful Resources. American Antiquity 68:333-352. DOI:10.2307/3557083.

Weasma, T.R. 1991. Field Report on Preliminary Testing of Cornet Bay Shell Deposits, Deception Pass Area, Whidbey Island, Washington. Unpublished Report on File at Washington Department of Fish and Wildlife.

Wolverton, S. 2013. Data Quality in Zooarchaeological Faunal Identification. Journal of Archaeological Method and Theory 20:381-396. DOI:10.1007/ s10816-012-9161-4. 